\title{
Transcending Paradigmatic Fractures: Reflections on a Critically Conscious Academic Identity through a Decolonial Lens
}

\author{
Ronicka Mudaly \\ ORCID iD: https://orcid.org/0000-0002-7347-2098
}

Vimolan Mudaly

ORCID iD: https://orcid.org/0000-0003-3570-1256

Nonhlanhla Mthiyane

ORCID iD: https://orcid.org/0000-0003-0547-3221

Doras Sibanda

ORCID iD: https://orcid.org/0000-0001-9328-3473

\section{Abstract}

For several years we, a group of mid-to-late-career academics in science and mathematics education, experienced increasing discomfort in our classrooms. Our professional anxiety intensified as we found ourselves trapped in the liminal space between the demands of the academic institutions, and the call of students to decolonise the curriculum. This was inextricably linked to our complicity in perpetuating the tradition of importing 'good' science and mathematics, grounded in Euro-western paradigms, and transplanting it into African classrooms, with its practices of epistemological exclusion. We were, and still are, uneasy about continuing to use science and mathematics education, which is informed by a monolithic canon, as a vehicle of fragmentation and conquest instead of leading towards social cohesion. Within this complex space we adopted narrative inquiry to become more thoughtful, retrospective, and introspective of our practice. We reflected on our past and present identities and our active agency in becoming 
more inclusive in the future. Using storyboarding and reflections we examined the activities we engaged in and people with whom we interacted, in order to develop our capacity to transcend that paradigmatic fracture between higher education and our community, by attempting to make science and mathematics education inclusive of African paradigms. The narrative arc of meaning within this temporal space in higher education suffused our academic selves with a critical consciousness, as we prepared to connect our students with their own knowledge and history.

Keywords: academic identity, cohesion, decolonisation, indigenous knowledge, narrative inquiry, transformation

\section{A Snapshot of the Higher Education Landscape in South Africa}

Although numerous policies have been implemented to promote inclusivity in higher education in South Africa after the first democratic elections, there remains a 'disjuncture' between what policies espouse and the experiences of students and staff in this sector (Bozalek \& Boughey 2012:688). This is more so for students and staff at historically black universities, which were governed differently and received significantly less funding than historically white universities. Poor funding had a negative impact on the availability of resources, the ability of historically black institutions to attract high-calibre academics, and the quality of education offered. In a bid to redress historically legislated discrimination, the South African Bill of Rights, which included the principle of equal access to education, was promulgated (Hall 2015). Among the ways in which this principle was enacted was the mandatory merger of several universities, Technikons and colleges of education, making up the current 26 higher education institutions (HEIs) in the country. However, divisions along the lines of race, type of institution, location and languages of instruction continue to stratify the higher education sector, reflecting the legacy of advantage and disadvantage and the hierarchy of status that were characteristic of the apartheid era (De Kadt 2020).

Like the rest of the world, South Africa has seen a massive growth in higher education, fuelled by the 'knowledge economy' discourse and demands for economic growth (Cloete, Mouton \& Sheppard 2015). With the 
advent of the era of access to higher education by all students, regardless of race, historically white universities have been flooded with black/African students, many of whom come from families from low socio-economic settings (Cloete et al. 2015). During the two decades after 1996, attendance in post-school education increased by $22.5 \%$ annually, driven by greater access for black/African students (Statistics South Africa 2017). At the same time, higher education funding has decreased in recent years, reflected in budget cuts and decreased per capita spending, leading to cash-strapped universities across the country resorting to large fee increases (Sayed 2017; De Kadt 2020). These budget cuts disproportionately affect historically black institutions, through rewarding research more than teaching in funding formulas. This is within a context where historically white institutions have enjoyed a long history of research and attracted and continue to attract students with excellent academic profiles, prolific researchers and published authors from high socio-economic groups (Bozalek \& Boughey 2012).

Any attempt to understand South Africa's higher education landscape therefore needs to consider the diversity of students' and staff experiences, and how institutional context shapes such experiences. While South Africa can be argued to have achieved access to higher education for the majority of students, there is a need to adopt a social justice lens in addressing the more fundamental student and staff challenges that impede real transformation of this sector. This is because the 'opening' of higher education has not responded to the ways in which racism and white supremacy are embedded in the very structure of education, such as funding, hiring and fees. Equality of access to higher education has not translated into access to knowledge or access with academic success (Leibowitz \& Bozalek 2014).

\section{Decolonising the Curriculum}

The lack of real transformation in higher education emanating from the structural inequalities that continue to characterise South African society as a whole, including education, culminated in calls by students to decolonise the curriculum (Heleta 2016). This resulted in the 2015/16 \#FeesMustFall student protests across South African HEIs. Heated debates in the academic sphere regarding the 'what' and 'how' of decolonisation have ensued. Badat (2017) posits that the 2015 student unrests led to a 'decolonial turn', which demanded a focus on decolonisation as a means to achieve the much-needed 
curriculum transformation. In contrast, Jansen (2017) uses the notion of 'curriculum as a flag' to argue that the call for decolonisation of the curriculum was symbolic on the part of students. He posits that although there is a need to transform the curriculum, the real student issues fuelling the \#FeesMustFall protest were materialistic by nature, including high university fees and the outsourcing of university workers. He does, however, allude to a need to fortify curricula with a plurality of knowledges from Africa, Asia and Latin America (Van Heerden 2017).

In arguing for a need to pay more attention to issues of transformation of the curriculum, Lange (2017) maintains that curriculum reforms changed only the 'exoskeleton' and left untouched the curriculum's 'endoskeleton', which addressed the 'content and quality' of what is taught. What is clear from all these accounts is that issues of curriculum transformation in South African higher education have not received enough attention. This paper presents four teacher educators' reflections on how their participation in a decolonisation project shape their academic identities, within a higher education landscape where views about coloniality and transformation abound.

\section{Setting the Scene}

We are a group of four academics, comprising three women, Doras, Nonhlanhla and Ronicka in science education and Vimolan, the only male member of the group, from mathematics education. A funded project titled 'Exploring possibilities for decolonising the science and mathematics education curriculum', on which we serve as core researchers, is a collaborative endeavour which brings us together. Each of us works in different research fields and has at least 12 years' experience in the academy. In this article, we transcend the 'psychological exclusiveness' that confines us to dominant 'definitions, theories and methods' that underpin our disciplines (D’Angelo 2002:872). We reflect on our epistemic choices, while cognizant of our location within masculinist, positivist disciplines of science and mathematics. Within these strong disciplinary boundaries, we question our complicity in the invisibilisation of 'genealogies of knowledge' (Iveković 2019:762) and tap into our agency to transcend racialised, ethnicised subjectivation, by imagining possibilities towards 'pluriversum' (Iveković 2019:764) in our practice.

Vimolan, Doras and Ronicka are located at a traditional research 
university that resulted from a merger between a previously white university, a previously Indian university and a previously white college of education. Nonhlanhla is located at a university of technology that resulted from a merger between a previously white Technikon, a previously Indian Technikon and a previously black College of Education. We share parts of our career trajectories, beginning as early career academics and transitioning into mid-to-late-career academics.

We use narrative inquiry to examine the shapers and re-shapers of our professional identities in the past, when we were novice academics at the beginning of our academic journeys, and in our present positions as midcareer academics. We introspect to understand how our professional identities influence our actions and are influenced by them, and our agency in this process. Our discomfort in the roles we play in perpetuating the western ways of doing science and mathematics as the only legitimate knowledge force us to reflect on alternative strategies for teaching the subjects. As we examine our microworlds, each of us is simultaneously a researcher and participant, and our researcher-constructed narratives are the same as participant narratives. The central question in our research is 'How do our reflections, both individual and collective, within a project on decolonising the curriculum, shape our academic identities?'

We borrow conceptual ideas of generativity from Erikson (1963), McAdams and De St. Aubin (1992) and Hofer et al. (2008) to make meaning of our identities. We begin by describing the dynamic context in higher education, which has reverberated with calls to decolonise the curriculum since 2015, and then we discuss the conceptualisation of academic identity. Next, we provide our understanding of storyboards as a 'visual, participatory research method' (Van Laren et al. 2013:2) and how we used it in our work. We present one storyboard created by the science academics and another created by the mathematics academic, as well as reflections from our diaries. The reason for generating two storyboards was that several areas of commonality emerged in the science members' accounts of the evolution of their academic identities, and these were markedly different from that of the mathematics member.

\section{Conceptual Framework}

We use Kogan's (2000) concept of academic identity as our framework to 
analyse our reflections of our journeys as academics. Academic identity embodies the distinctive individual, the embedded individual, and professional identity (Kogan 2000:210). The distinctive individual is the academic who 'has a unique history, who is located in a chosen moral and conceptual framework ...' (Kogan 2000:210). The academic is also an embedded individual, being located within a particular institution which has its 'own languages, conceptual structures, histories, traditions, myths, values, practices and achieved goals' (Kogan 2000:210). The professional identity develops at the intersection of the individual and the social, that is, between the individual and other people and institutional structures at the HEI.

In adopting a narrative stance to explore our shifting academic identities, we lean on Lawler (2009), who explains that identity is made up of a series of narratives that are influenced by an individual's background and culture. This articulates with Kogan's (2000:210) conceptualisation of 'distinctive individual'. We also find Hyland's (2018:1) view of identity relevant as an idea that can 'be explored through the stories we tell about ourselves, tapping into the accounts that individuals select, structure and relate at appropriate moments'. Hyland (2018:4) adds that identity is the 'product of the interaction of individuals and is created within social relations' and this corresponds with Kogan's (2000:210) description of 'professional identity'. The underlying emphasis of identity is on reflexivity and the belief that storytelling is an active process where authors re-present a particular aspect of their lives. These stories are usually created within a social context (Hyland 2018). In our group, we capture our individual stories by using different data sources such as storyboards and diaries. We analyse ideological assumptions which underpin our 'academic pedagogy and practice' (Mudaly 2012:38). In doing this we do not weave our stories into the fabric of academic life using a discourse based on deficiency and victimhood (Mudaly 2012); instead, we provide insight into how we created opportunities for learning to underpin our thinking and practice within a social justice ideology.

\section{How We Storied our Stories}

We adopted a qualitative narrative approach to explore our lived experiences of social cohesion, and how these experiences shape our academic identities in our endeavour to decolonise the curriculum. We do not use the words 
'decolonial' and 'decolonise' without trepidation. Many experiences helped us to conceptualise decoloniality. For example, we had attended Decoloniality Summer Schools from 2019 to 2020, and similar programmes where domination, exploitation and other principles of coloniality were debated. Hegemonic principles that underpin the normative understanding of knowledge, within broader inquiries of what is progress, modernity and development, and for whom these are intended, led to introspection and debates among ourselves and our colleagues. Spurred on by the \#FeesMustFall protests, which were rooted in multiple forms of disenfranchisement, we committed ourselves to examine our work through a decolonial lens. Our epistemological roots are embedded in Euro-western traditions. Yet we look beyond our familiar interpretive horizons, as we reconceptualise who we are and how we work in a higher education landscape that reverberates with calls for transformation. In engaging with decolonisation, we reflect on epistemological alienation, the cry for decolonising the curriculum, and knowledge and power, and how we demonstrate our agency within this socio-cultural context.

Our understanding of 'decolonial' was shaped by our experiences of oppression during the apartheid era, our marginalisation and that of our students, rooted in the legacy of socio-political discrimination, our reading and discussion of these terms from works by Nelson Maldonado-Torres, Sabelo Ndlovu-Gatsheni, Lesley le Grange, Fanon and Paulo Friere, among others. The abyssal margin of separation of people into zones of being and non-being, the need for culturally responsive pedagogy and what mitigates against this - especially deliberate epistemic blindness which upholds the existing hegemonic order - shaped our decolonial lens. Blackness is associated with those who lie below the human colour line, and is a subaltern space characterised by violence, dispossession and poverty. People within this space are classified as not fully human, and the abyssal line demarcates 'us' from 'them' (Ndlovu-Gatsheni 2018). We also understood gender as a colonial category and reflected on the 'subaltern female subject' (Radlwimmer 2017:16) especially in academia. Each member of our group, by virtue of our race, class and, in the case of the female members, gender disadvantage, experienced 'othering', borne out of our location in the zone of non-being. We believed that a decolonial lens can provide insights into reclaiming human identity, and sought avenues for denormalising epistemic hegemonic narratives (Prinsloo 2020). We wanted to reclaim a fully human 
identity for ourselves and our students, and sought to do this through our work in higher education. These ideologies, which informed our human and academic identities, motivated us to step into the murky conceptual landscape of decolonisation.

A qualitative approach was suitable in our study because it enabled exploration of 'experience, meaning and perspective, most often from the standpoint of the participant' (Hammarberg, Kirkman \& De Lacey 2016:498). We leveraged conceptual and methodological tools from narrative inquiry to inform our meaning-making journey. The narrative approach is appropriate for this study because it links with our concept of academic identity, as shaped by our academic experiences, histories and stories.

Narrative inquiry embraces a variety of approaches, such as biography, autobiography, life story and life course research. It can also focus on studying people's experiences written as stories (Elçi \& Devran 2014; Clandinin, Pushor \& Orr 2007), and this understanding is buttressed by Savin-Baden and Van Niekerk (2007). Narrative inquiry provides a person with a platform to construct a story about his/her life. The story usually has a beginning, a middle and an end (McAlpine 2016). These stories usually focus on different issues, such as inequality, oppression, exploitation, subordination, lack of understanding or acceptance. The researchers sometimes retell these stories in a narrative chronology (Creswell \& Creswell 2018). Narrative inquiry 'involves telling stories, recounting - accounting for - how individuals make sense of events and actions in their lives with themselves as the agents of their lives' (McAlpine 2016:34). In this narrative inquiry we refer to lived stories about our academic lives that are shaped by our histories, cultures and experiences.

In our study we adopt a shared socio-cultural approach. We present rich descriptions of our stories, based on how we exercised our agency during our experiences of a complicating event - decolonisation. Narrative inquiry, then, is useful in our search for meaning and making sense of our academic selves. In looking back and then to the present and future, we recalled our memories and expressed feelings that these evoked, using diaries and storyboards as research instruments. These were developed during a period of one year, when other activities, including seminars and participation in reading circles, occurred. We discuss these approaches before moving on to our analyses. 


\subsection{Diaries}

Sheble and Wildemuth (2009:1) explain that diaries are useful instruments in qualitative research, because they are 'distinct in that time structures their creation, layering text and objects into a chronological composite of snapshots and reflections ...' . We created semi-structured diaries, and used a decolonial lens to reflect on the following: (1) the ideology which underpinned our practice in the past and how this shaped our academic identities; (2) events or moments which raised our critical consciousness as academics; and (3) how our academic identities, which were suffused with heightened critical consciousness, will influence our future thinking and doing. Each diary captured a narrative account of personal, lived academic experiences.

\subsection{Storyboarding}

Storyboarding occurs during the planning process for making a film or video, and is touted as a powerful visual research method (Mitchell \& De Lange 2011). A storyboard maps out a series of scenes that are used to develop a story in a film or video. In this paper, storyboards were used to capture the essence/key events of our careers, which dictated the trajectory of our academic identities as we engage with the concept of decolonisation.

Storyboarding is an arts based, participatory, visual method. It is particularly useful in research which is underpinned by a social justice imperative. For example, Greene contends that arts-based methodologies enable 'a centrality of imagination because of its power to enable persons to reach toward alternatives, to reach beyond ... [to] open windows in experience, provide moments of freedom and presence, [and] enable us to break with terrible moments of apathy and numbness' (Greene 2007:2). Researchers who have leveraged affordances of arts-based methodologies towards a social justice aim, and who adopted a decolonial lens, as we did, include Osei-Kofi, Shahjahan and Patton (2010). Storyboarding was useful in our study because, borrowing from these researchers, it offered the 'possibility of different, non-linear forms of discovery, knowing, and interpretation' (Osei-Kofi 2013:140). It also provided a platform for us to engage in 'living inquiry' (Osei-Kofi 2013:146) of our academic journeys and how these shaped our identities. We borrow the definition of a storyboard from Van Laren et al. (2013:4), which is 'a structured and pre- 
planned visual outline or skeleton that comprises a series of drawings, sketches or explanations representing each scene or camera shot required to produce a video'. The process of generating our storyboards served as an intervention and a space for transformation, both of our professional identities and of our practice (Mitchell 2008).

\subsection{Working with Storyboarding and Diaries}

We first used semi-structured diaries, which we maintained over a year to reflect on the complexity of each of our experiences. Between 10 and 14 reflections on past and present experiences were recorded. Based on the semi-structured diaries, we then developed storyboards, which created an 'imaginative, tangible, and reflexive space' (Naicker, Pillay \& Blose 2020:128) for us to work within a narrative inquiry approach. Storyboarding was used as a participatory method to reflect and introspect on our professional identities before and during our engagement in the project. Three workshops were held, and at the first, two members of the project team presented their understanding of what a storyboard is. A colleague who is an expert in visual methodologies but was not a part of our project group also helped us to conceptualise storyboarding.

Due to the COVID-19 pandemic restrictions, we were unable to meet in person to develop the storyboards. However, we used the three workshops, which were held via Zoom, and several emails and telecommunications to develop a common storyboard which captured the stories of the three science academics with a separate storyboard for the mathematics academic.

Guided by the steps for the storyboarding and reflective process outlined in Van Laren et al. (2013), we began by holding a Zoom workshop to discuss key questions to guide our diary reflections. We also discussed our understanding of what storyboarding as a research method entails, using published articles and book chapters which focused on storyboarding. We shared more articles after the workshop to build our capacity to engage in the storyboarding process. A second Zoom workshop was held where we read accounts from our diaries aloud. Our reflections were different, but we distilled key issues which were important in the formation of our academic identities from the diaries. We discussed these key issues and decided that our academic journeys revealed that 'social inclusion' and 'a decolonial lens' were important and should be included in our storyboards. 
We worked collaboratively in discipline-aligned groups and decided that we would have one storyboard for mathematics and one for science, because different rules and practices inform these two distinct disciplines. We planned that Vimolan would construct the mathematics storyboard, while Doras, Nonhlanhla and Ronicka would construct the science storyboard.

The next step involved delving into one another's reflections and recording our understanding of these in our diaries. We shared these interpretations at the third workshop. The purpose of this was to immerse ourselves in the hearts, minds and feelings of each other, in order to understand one another's lived experiences. Based on these reflections, each of us in the science discipline constructed an individual storyboard, which we shared via email.

All members then met, where reflections were re-read, and we studied the individual storyboards. The science members selected specific frames from the three storyboards to generate a single storyboard that resonated with each science member's academic journey. The mathematics member was involved in all meetings, and our collective deliberations shaped our stories. This involved what Creswell and Creswell (2018) refer to as peer debriefing. Our retelling of the story using storyboards 1 and 2 was a 'means of understanding experience as lived and told' (Savin-Baden \& Van Niekerk 2007:459).

In constructing the storyboards, we made our academic and pre-academic selves more visible. This was based on introspection on our workplace practices, and caused an unravelling of our own identities that were influenced long before we had become academics. In this highly performative environment, academics are evaluated on community engagement, student performance, research outputs and curriculum completion. The content that the academic teaches is limited by the curriculum templates, which satisfy national norms, peer reviews and vocational expectations. Intrinsic rewards and satisfaction of engaging meaningfully with the content by adapting it to local needs must be scrutinised carefully and worked within the ambit of the curriculum templates. 


\section{Critically Conscious Academic Identity through a Decolonial Lens}

\section{Storyboard 1}

\begin{tabular}{|c|c|}
\hline $\begin{array}{c}\text { Science teacher educators' academic journey } \\
\text { from early to mid-career: Gazing through a } \\
\text { decolonial lens }\end{array}$ & $\begin{array}{l}2 \text { Higher education halls of learning } \\
\text { INEQUALITY } \\
\text { Black student denied access and success in science. Black } \\
\text { students intimidated by white lecturers, white students, } \\
\text { white science which is irrelevant to their world. } \\
\text { Fragmentation, isolation, humiliation, competition, } \\
\text { separation, peripheralization of black students ... and we } \\
\text { are COMPLICIT! (opening our eyes?) }\end{array}$ \\
\hline $\begin{array}{l}3 \\
\text { WHO ARE WE WITHIN THIS SPACE? } \\
\text { Black women, junior rung on hierarchy, high } \\
\text { workload - handmaidens of knowledge class. } \\
\text { CANNOT ROCK THE BOAT - WE ARE } \\
\text { VULNERABLE, INEXPERIENCED. Complete } \\
\text { PhD first. Establish as credible knowledge } \\
\text { producers, not employed to satisfy employment } \\
\text { equity rules but as a real, worthwhile academic }\end{array}$ & 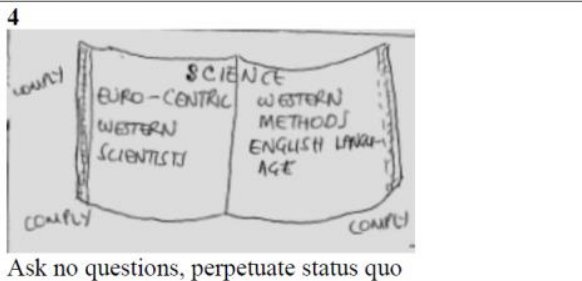 \\
\hline Opening our eyes/Broadening our vision & $\begin{array}{l}\text { I W ANT THS } \\
\begin{array}{l}\text { Reading: Gatsheni, Le Grange, Fanon, Friere } \\
\text { Seminars }\end{array}\end{array}$ \\
\hline $\begin{array}{l}\text { Science Project : } \\
\text { my AHA I Monuent }\end{array}$ & 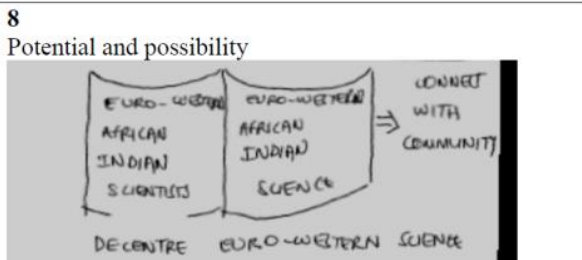 \\
\hline $\begin{array}{l}\text { \& A SAFE SPACE! FEEUING } \\
\text { CONNECIED! }\end{array}$ & $\begin{array}{l}\text { Collaboration } \\
\text { Inclusive pedagogy, reflexive practice } \\
\text { Change } \\
\text { Transformation of PEDAGOGY-methods - use talking } \\
\text { circles, storyboarding - flexibility - students express } \\
\text { themselves using drawings instead of text, linguistic } \\
\text { barriers reduced }\end{array}$ \\
\hline
\end{tabular}

Figure 1: Storyboard by Doras, Nonhlanhla and Ronicka: Science teacher educators' academic journey from early to mid-career: Gazing through a decolonial lens 


\section{Storyboard 2}

\begin{tabular}{|c|c|}
\hline $\begin{array}{l}1 \\
\text { Trying to transcend } m y \text { fractured paradigm }\end{array}$ & $\begin{array}{l}\text { African } \\
\text { indigenous } \\
\text { The dominance of Euro-Western knowledge economy } \\
\text { in Africa } \\
\text { western }\end{array}$ \\
\hline $\begin{array}{l}\text { Our children in Africa also need globally accepted } \\
\text { mathematics in the 4th IR }\end{array}$ & $\begin{array}{l}\text { 4. Social Justice } \\
\text { The mathematician (positivist) in me is troubled by } \\
\text { the social justice echoes that are being thrown about }\end{array}$ \\
\hline $\begin{array}{l}\text { I am caught up in a zone of absolute discomfort and, } \\
\text { as a purist I find that the disquiet that engulfs me is } \\
\text { difficult to endure }\end{array}$ & $\begin{array}{l}\text { Indigenous knowledge has its space but in the current } \\
\text { curricula it is limited to contextual factors }\end{array}$ \\
\hline $\begin{array}{c}\text { Real } \\
\text { mathematics } \\
\text { to become } \\
\text { subsumed into } \\
\text { the contextual }\end{array}$ & \begin{tabular}{|l|l|l|l|l|l|} 
& & & 1 & 1 & 1 \\
& & & 1 & 1 \\
$\bullet$ & - & & 1 & 0 \\
$\bullet$ & & - & 1 & 1 \\
$\bullet$ & $\bullet$ & - & 1 & 1 \\
$\bullet$ & $\bullet$ & $\bullet$ & 1 & 1 \\
\end{tabular} \\
\hline $\begin{array}{l}\text { Most relevant mathematics cannot always be } \\
\text { located in contextual factors }\end{array}$ & $\begin{array}{l}\text { Foregrounding the indigenous voices and practices of } \\
\text { previously marginalised groups must occur in early } \\
\text { schooling }\end{array}$ \\
\hline $\begin{array}{l}\text { But we need to demythologise the idea that by } \\
\text { simply decolonising the curriculum in mathematics, } \\
\text { one can offer students a better life in an unequal } \\
\text { society }\end{array}$ & $\begin{array}{c}\text { Our inability to recohtextualise and indigenise } \\
\text { mathematics does not mean that decolonisation is } \\
\text { futile }\end{array}$ \\
\hline
\end{tabular}

Figure 2: Storyboard by Vimolan: Trying to transcend my fractured paradigm 
McCune (2019:2) dichotomises the relationships between research and teaching as being,

highly complex and cannot be simply represented as an obvious synergy or a straightforward relation of tension and competition between the two. Rather the relationships are enacted differently by diverse academics shaped by multiple discourses and complex interplay between beliefs about learning and teaching and understandings of the nature of knowledge.

In trying to address the notions above, we chose to use McAdams and De St Aubin's (1992) model of generativity (Figure 3), as adapted by Hofer et al. (2008:3). Hofer et al. (2008:1) cite Erikson (1963:276), who described the concept of generativity in his theory of psychosocial development as 'the concern in establishing and guiding the next generation'. Stevens and Patel (2015:160) also recognise Erikson's theory as the,

interplay of an individual with the external social factors around them. During the stage of generativity, adults are faced with the struggle to give back to society and become something greater than themselves through their careers and/or families.

The model by Hofer et al. (2008:3) includes six different features that are interconnected. The model recognises two layers - cultural demands and inner desires - which are motivational sources.

Cultural demands in South Africa (student protests related to decolonising the curriculum, for example) have resulted in a rethinking of our curricula and teaching. With the ongoing uncertainty around university transformation, many academics have themselves begun to intrinsically desire a change - inner desires - towards a more inclusive and indigenised curriculum. These two sources of motivation often lead to the creation of thoughts and plans in preparation for a change in behaviour. The concerns brought on by the motivational sources induce specific commitments or goals. These goals are then enacted, indicating concrete generative behaviour. In acting on these goals, meaning is conveyed through the narratives that emerge, as we story our academic selves from early to midcareer, and imagine the future (emphasis added). 
Ronicka Mudaly et al.

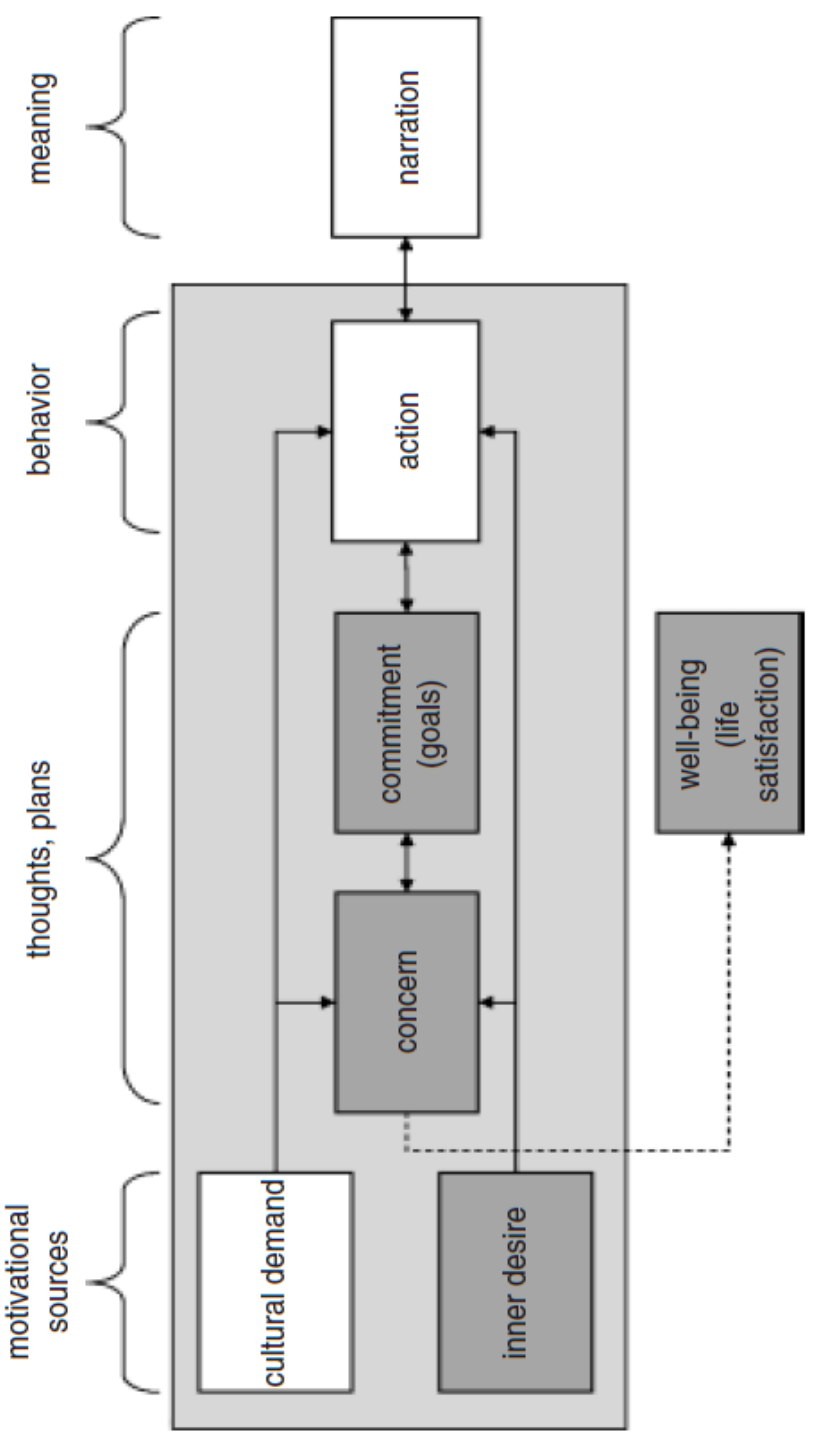

Figure 3: Model of generativity proposed by Hofer et al. (2008:3) 


\section{Entering the Ivory Tower}

We draw on our diaries and storyboards to make sense of our early years in academia. The three science colleagues (Ronicka, Doras and Nonhlanhla) were women academics, who worked on Storyboard 1. The meaning that they ascribed to their academic experiences was significantly influenced by cultural demands, namely those related to inequity and fragmentation. Evidence of this in Storyboard 1, frame 2, includes: 'Black students denied access and success in science', 'Black students intimidated by white lecturers, white students and white science, which is irrelevant to their world' and 'Fragmentation, isolation, humiliation, competition, separation, peripheralization of black students ...'. These ideas were generated after the science academics had discussed their diary entries. For example, Nonhlanhla disclosed the following about her university life which raised her political consciousness:

Strikes, police, and soldiers pointing guns at us were a 'normal' feature of my university life. Although we were told many times by our white lecturers, many of whom were part of the army that attacked us during strikes, that we should never 'mix' education with politics, our lived experiences as black university students taught us that education is political by its very nature.

Nonhlanhla's account of her pre-academic self reveals the violent environment rooted in racial fragmentation which she was immersed in, which heightened her political consciousness. Nonhlanhla's allusion to white and black, without considering the 'Indian' and 'Coloured' race categories in South Africa is not unusual. Race theorists express racial categories as 'white' and 'black' (Matthews 2015:113). Even the Freedom Charter indicates that 'South Africa belongs to all who live in it, black and white ...' (Mhlauli, Salani \& Mokotedi 2015:206).

The inequity and marginalisation suffered by black students made her a more conscious practitioner once she entered academia, and this is evident in her assertion that 'education is political by its very nature'. That HEIs were used as 'creatures of the (apartheid) state' (Bunting 2006:37) is evident in Nonhlanhla's assertion that white lecturers who were part of the 
Ronicka Mudaly et al.

pro-apartheid army instructed them not to 'mix' politics with education, in order to maintain the unequal social order.

Doras suffered anxiety borne out of different markers of exclusion and inequity, which is evident in the following diary entry:

My early years as an academic were not smooth being a black woman of foreign origin in a space that was meant for the privileged.

A subaltern identity was also formed by Ronicka, who made the following diary entry to capture her angst as a novice academic:

I was acutely aware of the multidimensional disadvantage of being brown (in a liminal space, unable to leverage advantages of ontological density of my white counterparts, and wary of the assumption that I was possibly accepted into higher education based on the employment equity policy of the institution), and being a woman within a patriarchal higher education landscape

The complexity of women's academic identity has been well documented (Husu 2001). The 'racialised and gendered asymmetries of power' at play (Mudaly 2015:39), women's under-representation in upper echelons of the academic hierarchy (Naicker 2013; Shober 2014) and structural barriers to their progress (Mama 2006) shape women's identities, experiences and professional practices in particular ways.

Vimolan remembered (Sellitti 2009) his entry and progress in academia in the following diary entry:

My entry into a[n] HEI filled me with excitement. I had at my disposal many resources, and was given the opportunity of leading the work-integrated teaching practice programme for the entire school when I was only in my second year of academic life. In my third year I was promoted to Senior lecturer, in my 14th year to Associate Professor and in my 15th year, to full Professor. I led the local organising committee of several conferences and was called upon to act as Head of 
School on multiple occasions. These achievements I attribute to my confidence, and hard work. In 2017 I was listed among the top 30 researchers in the entire institution.

The anguish, anxiety and trepidation in the women's early-career accounts were absent from the male member's reflection. Vimolan assumed leadership positions from his second year and was the only full professor in our group. He attributed his success to a well-resourced environment and being confident and working hard. What was evident was that the intersectionality of historical, socio-political and cultural contexts yielded heterogenous experiences among academics, which, according to Ramohai (2019), is under-researched.

\section{Complicating Events Inside the Ivory Tower}

In Storyboard 1, the women academics reported having occupied 'junior rungs' on the (academic) hierarchy when they entered the HEI, and spoke about the high teaching workload ('handmaidens of the knowledge class'), which allowed little time for research and community engagement. Yet they remained mute for fear of 'rock(ing) the boat - we are vulnerable, inexperienced' (frame 3). Gender is a colonial category, and Radlwimmer (2017) underscores the subalternity and silencing of the female subject, which echoed in the stories of some members of our group. This supports the view that higher education is a 'tough industry' (Shober 2014:324). Naicker (2013) has reported on how women academics, who bear a disproportionate load of teaching, cannot ascend towards the upper echelons of the academic hierarchy.

The status quo, related to the cultural demands of the HEI, about what content can be taught, the pedagogy to be used and the knowledge producers to be valued, was a complicating event because it was Eurocentric and marginalised alternative knowledges and knowledge holders (Storyboard 1, frame 4). Similarly, Osie-Kofi (2013) drew on findings from other research to underscore the monolithic lens that has been normalised, because the scientific method is deemed to be the only valid way to generate useful knowledge.

Vimolan, who worked on Storyboard 2, viewed the complicating events quite differently. Like the science academics, he recognised 'the 
dominance of Euro-Western knowledge economy in Africa' but felt that 'our children in Africa also needed globally accepted mathematics in the 4th industrial revolution'.

There was robust discussion during our meetings and workshops about the inner desires, and it became evident from the conversations that ensued that mathematics and science were masculinist disciplines and were viewed differently among group members. Despite their awareness of the ubiquitous knowledge paradigm that was promoted in the HEI, the science academics identified their inner desires as 'Complete my $\mathrm{PhD}$ first', 'Establish ourselves as credible knowledge producers, not wanting to be seen to be employed to satisfy employment equity rules but as a real, worthwhile academic' (Storyboard 1, frame 3). In contrast, Vimolan became uncomfortable and stated his inner desires as 'the mathematician in me is troubled by the social justice echoes that are being thrown about. I am caught up in a zone of absolute discomfort and, as a conscious practitioner I find that the disquiet that engulfs me is difficult to endure' (Storyboard 2, frames 4 and 5). It was becoming evident that discussions were creating inner turmoil for some. During the initial discussions Vimolan argued that mathematics was a rigid subject comprising a corpus of knowledge that was not malleable, and as a result, curriculum transformation would be a challenge.

\section{Concerns in the Ivory Tower}

The resultant concerns, as expressed by Ronicka, Doras and Nonhlanhla in the first storyboard, were deep and came from intensive introspection on their academic experiences. The first was that as novice academics, during their early career they felt intimidated by their low status and remained muted (Ramohai 2019), retreating to a safe place where they asked no questions (Storyboard 1, frame 4). They simply perpetuated the status quo because they did not want to be seen as disruptive. This was significant and showed the pervasive influence of the intensely patriarchal, colonial structure of the HEI.

In contrast, Vimolan's concerns were not as personal and focused on the discipline of mathematics. He expressed the concern that indigenous knowledge has its space but in the current curricula is limited to contextual factors, and that most 'relevant' mathematics cannot always be located in contextual factors. Vimolan's concerns were about the nature, rules, laws and 
language of mathematics, and how it could be re-imagined using conceptual tools from indigenous knowledge. This was unlike the concerns revealed on Storyboard 1, which revolved around inner feelings and emotions. For Vimolan the allure of a more epistemically just curriculum which offered a more 'African-centred' perspective (Heleta 2016) was real; however, the design of such a curriculum, which would simultaneously render learners globally competitive, was far from simple.

\section{Commitments and Goals in the Ivory Tower}

The concerns raised in Storyboard 1 resulted in commitments and goals among the science members to transform themselves as their identities evolved through individual and group reflections. The initial reaction was that this process of unveiling 'opened our eyes', and was an avenue for greater consciousness raising. The explicit acknowledgement that they are part of the problem and would need to become proactive in order to make a difference was crucial. In order to do this, the science members recognised that they would need to 'unlearn and then re-learn through a strong commitment to decolonisation' (Nonhlanhla's diary entry). They decided that indigenous communities must be involved through consultations and invitations to deliver talks and workshops during module presentations. This will ensure greater cohesion between the University, indigenous knowledge holders and students. The promotion of cohesion through the curriculum by promoting the valuing and development of African cultures has been underscored by UNESCO (2014).

In Storyboard 2, Vimolan's commitment was closely associated with his concerns, and he proposed that 'foregrounding the indigenous voices and practices of previously marginalised groups should occur in early schooling' (Storyboard 2, frame 8). He contended this is what mathematics educators should agitate for. However, he believed that adding contextual factors to mathematics could detract from essential concepts and mislead learners. For example, using the cone-shaped roof of traditional African huts to teach about the area of a cone should not detract from mathematical formulae related to the area of a cone. Vimolan felt that 'we need to demythologise the idea that by simply decolonising the curriculum in mathematics, one can offer students a better life in an unequal society' (Storyboard 2, frame 9). He based his argument on the fact that mathematics itself was a strongly 
classified (in the Bernsteinean sense) subject, and changing it could retard the progress of learners in critical fields. He experienced the angst of the moral and pedagogic impetus to disrupt the marginalisation of African knowledge in the curriculum, and the disquiet that such a disruption could not yield the benefits which equality promises (Storyboard 2, frames 8 and 9). Challenges which Vimolan believed needed to be addressed were how to digress from monocultural perspectives of what is 'legitimate' mathematics, by 'crawling through a new curriculum wormhole' (Kincheloe 2008:8), and how to 'disrupt the epistemological status quo' (Mudaly 2018a:63).

\section{Action in the Ivory Tower: Daring to Imagine a Different Academic Self}

In changing our behaviour, several actions were noted. All colleagues began reconciling activism with scholarship in our quest to sever those cables which bound us to a monolithic view of knowledge, that which Shiva (1993) refers to as monoculture of the mind. We engaged in reading circles where we focused on the works of, among others, Nelson Maldonado-Torres, Sabelo Ndlovu-Gatsheni, Lesley le Grange, Fanon and Paulo Friere. Four seminars, facilitated by leading decolonial theorists who we regarded as experts, were organised during the year by the members of this project, and students were invited to participate. The intention was to improve our own knowledge and conscientise ourselves and our students for the future. We anticipate that our transformation as academics will filter to our students, many of whom are practising teachers, to raise their awareness about decentring Euro-western paradigms in science and mathematics as a route towards decolonising the curriculum. In reflecting and engaging, we affirmed the idea that agency in effecting change has to start with ourselves.

The following diary entries reveal how we exercised our agency to build our capacity to decolonise the curriculum:

Doras: from the Reading Circle, I learned that the Gatsheni view describes people as belonging to two zones. The zone on being which show that someone is superior and the zone of nonbeing to indicate an inferior person. The Europeans are viewed to be people who abide by the law and lawlessness describes a black person. 
Being part of this project has made me have a closer look at what I am doing as an academic, what kind of knowledge I am sharing with my students. As an academic in science education, I used Euro-western examples without reflecting on the lack of relevance of these for my learners. For example, when teaching about matter and materials, I could refer to objects with which students are familiar, such as unfired clay pots which are important African appliances, which keep contents cool because they have low thermal conductivity. The knowledge gained in this project has influenced the way I view what I teach and for whose benefit.

Doras introspected on the relevance of the content she was teaching her students, and this marked a transformation of her academic self, a 'wide awakeness, ready to pay active attention to what has become so questionable and so troubling, ready to take that kind of action which will move (her) ahead into the future' (Greene 1971:10).

Nonhlanhla: Through collaborative reflections on readings on the 'coloniality of being and coloniality of knowledge', and seminars by Prof Le Grange, Prof Ramrathan and Prof Pillay, I am more aware that the effort to decolonise begins with myself; and I have to engage in a process of 'unlearning and relearning' as a science teacher educator. I see how I have left unchallenged the idea that knowledge that matters is knowledge from the North, and that there is nothing from mine and my students' contexts (African and local) that contributes to scientific knowledge. I have perpetuated the notion that producers of scientific knowledge are people other than Africans, and that they (my students) are only consumers of knowledge. My collaboration with my fellow science and mathematics teacher educators has created a safe space where we can be honest with each other about our teaching and what informs our practice. The social connections we are developing as a 'community of practice' of critically conscious science and mathematics teacher educators has a potential to create a deep sense of social cohesion among us as teacher educators. This 
Ronicka Mudaly et al.

will hopefully have a ripple effect into our classrooms, creating a pool of critically conscious science and mathematics teachers. Creating classrooms that nurture positive relationships, solidarity, cooperation, communal learning, where the success of all students instead of a few is encouraged, is what I will strive for.

Nonhlanhla wanted to start with herself, to 'engage in a process of unlearning and relearning' which resonated with the vision for the future for each of us. Her consciousness of epistemic (and possibly ontological) exclusion (Mudaly 2018a) is palpable in her comment 'there is nothing from mine and my students' contexts (African and local) that contributes to scientific knowledge ...'.

Vimolan implemented the lessons he gained from the project by designing a research task for his students where he invited them to apply a decolonial lens to a unit of work (Mudaly 2018b). His students showed an initial reluctance to change the way they teach. Many viewed mathematics as unchanging, producing standard, single solutions. In engaging with the activity in this research, they found it difficult to find suitable examples of recontextualised, indigenised ways of teaching the common mathematics prescribed in the Curriculum Assessment Policy Statement Vimolan indicated that this was mainly due to students' lack of experience and engagement in activities that engendered ideas of teaching mathematics from a local, indigenous perspective. Students were aware of the concept of decolonisation but had not themselves applied their minds to realigning their thoughts towards how they could change their teaching. Although Vimolan's storyboard reveals his angst at the moral and practical implications of indigenising the curriculum, he declares that his students' 'inability to recontextualise and indigenise mathematics does not mean that decolonisation is futile' (Storyboard 2, frame 8). Vimolan developed the belief that working towards dismantling knowledge power relations using a decolonial lens was crucial, although he found it challenging to change the pedagogy and content mathematics in significant ways.

In addition to attending seminars and reading circle sessions, Ronicka also collaborated with other academics to develop her capacity to work on the project.

She wrote as follows in her diary: 
(My collaboration with) other academics who worked in transdisciplinary spaces and valued a social justice approach to science education in particular, made me increasingly confident to venture beyond my familiar disciplinary boundaries. I began to believe that the tenor of science education can be changed. I reconceptualised parts of the modules I taught and experimented with key projects in the modules. I changed an existing project which focused on gardening for health, into a project which focused on cultivating African indigenous plants for health ... I then ventured further and engaged African indigenous knowledge holders as guest lecturers ... I paid for these lectures from my cost centre ...

Ronicka became increasingly courageous to step outside the disciplinary boundaries of science and develop her modules to incorporate African knowledge systems, by collaborating with activists for socially just education. She developed her modules differently and changed the content of her modules to incorporate African indigenous knowledge. She also positioned African indigenous knowledge holders as legitimate teachers in the HEI by inviting them in from the community to teach in the academic space. These indigenous knowledge holders were paid from Ronicka's cost centre. This 'tapping into locally based and locally produced indigenous knowledge ... by interweaving this with other forms of knowledge ... blurred the lines between indigenous and colonial, and between non-western and Western knowledge' (Mudaly 2018a:62).

\section{Concluding Remarks}

As producers and interpreters of data (Mitchell 2008), we presented a 'narrative visibility' of ourselves (Kim 2016:208). The concerns raised in Storyboard 1 resulted in commitments and goals being established for us to begin to transform ourselves as our identities evolve through individual and group reflections. It is important that these 'narratives, when told to others, may also influence how others see the storyteller' (McAlpine 2016:4). Mendieta (2013:137) argues that 'stories not only highlight an existing relationship between the narrator and listener/reader, but they also expose issues related to both identity and cultural membership'. These stories are 
powerful in such a way that they can influence how the narrator views him/herself and makes decisions to act (Holley \& Colyar 2009, cited in McAlpine 2016).

Our stories reveal how our group found the seminars and reading circles on decolonising the curriculum to be enlightening, and how this bolstered our confidence to transform our thinking and practice, as evident in the diary entries as well as frames 5,6 and 7 on Storyboard 1. The findings from the reflections show that our ideologies have been co-constructed and shared with students who participated in the curriculum decolonisation project. This marked an awakening of our academic selves, and we yearned to become conscious practitioners (Greene 1971).

We were very clear about what new steps we will each engage in as a way of emancipating our students and working towards a cohesive community. Cohesion and collaboration were key elements in the evolution of our academic identities. Vimolan arranged for his students to venture beyond the sacred walls of the lecture theatres, into communities, to tap into the knowledge of elders to inform their teaching. This marks a cohesion between the community and the university, because knowledge of community members was leveraged to indigenise a unit of work. Knowledge valued by the community as well as that of individual indigenous knowledge holders became crucial repositories in this project.

Doras decided to connect the 'what' to the 'who' of her teaching to make the work more relevant to her students. Her assertion was that cohesion could be promoted by designing a more meaningful curriculum, aligned to the needs of her students; this would engender a sense of belonging among her students in terms of the science she was teaching. For Nonhlanhla, her collaboration with members of this research group provided a 'safe space' for introspection into her academic self, and she drew courage from the support provided by the group, which she viewed as a cohesive unit. This motivated her to think and do academia differently.

Ronicka collaborated with experts outside of the group: academics who were activists for social justice. This signalled cohesion with likeminded academics. In addition, she fostered cohesion with the community by positioning indigenous knowledge holders as legitimate teachers in academia. Cohesion was also realised by including African indigenous knowledge content in her modules, and in doing this the possibility for transformation by decentring Eurocentric paradigms became real. 
Our academic identities underwent transformation, triggered by cultural demands and our inner desires. Although conscious of the social inequity, fragmentation and exclusion in higher education, the science members believed they began their journey on the 'wrong' side of the experienced/ inexperienced, white/non-white, man/woman binary. This made them compliant and passive and they perpetuated the status quo, even when it promoted inequality and exclusion, the latter of which were complicating events. A change occurred when all four members collaborated on a project towards decolonising the science and mathematics curriculum, and our concern about our complicity in perpetuating the status quo was heightened. As active agents who were invested in the transformation of our practice informed by a social justice ideology, we arranged and participated in seminars and reading circles. We viewed this as an intellectual, political and pedagogic initiative, and participated in debates, discourses and presentations about global and institutional inequality. We worked as a cohesive unit with experts and with one another, and developed academic courage to transcend familiar boundaries of thinking and doing. This feeling of connectedness was enhanced when we tapped into knowledge from the community and brought it into the HEI for our students to value their own knowledge by reconnecting to it.

\section{Acknowledgement}

This research was funded by the National Research Foundation Grant number 121283.

\section{References}

Badat, S. 2017. Trepidation, Longing, and Belonging: Liberating the Curriculum at Universities in South Africa. University of Pretoria Public Lecture Series on Curriculum Transformation Matters: The Decolonial Turn, 10 April 2017. Available at:

https://www.researchgate.net/publication/316736379_Trepidation_lon ging and belonging Liberating the curriculum at universities in S outh_Africa (Accessed on 22 July 2021.)

Bozalek, V. \& C. Boughey 2012. (Mis)framing Higher Education in South Africa. Social Policy \& Administration 46,6: 688 - 703. 
Ronicka Mudaly et al.

Available at: https://repository.uwc.ac.za/bitstream/handle/

10566/497/BozalekHigherEducation2012.pdf?sequence $=1 \&$ isAllowed =y (Accessed on 21 July 2021.)

https://doi.org/10.1111/j.1467-9515.2012.00863.x

Bunting, I. 2006. The Higher Education Landscape Under Apartheid. Available at:

https://www.ses.unam.mx/curso2017/bibliografia/Bunting\%202006\%2 0HE\%20under\%20apartheid.pdf (Accessed on 20 February 2021.)

Clandinin, D.J., D. Pushor \& A.M. Orr 2007. Navigating Sites for Narrative Inquiry. Journal of Teacher Education 58,1: 21 - 35. Available at: https://www.researchgate.net/publication/235282657_Narrative_inquir y_in_teaching_and_teacher_education (Accessed on 22 July 2021.) https://doi.org/10.1177/0022487106296218

Cloete, N., J. Mouton \& C. Sheppard 2015. Doctoral Education in South Africa: Policy, Discourses, and Data. Cape Town: African Minds.

https://doi.org/10.47622/9781928331001

Creswell, J.W. \& J.D. Creswell 2018. Research Design: Qualitative, Quantitative, and Mixed Methods Approaches. $5^{\text {th }}$ edition. Los Angeles: SAGE.

D’Angelo, P. 2002. News Framing as a Multiparadigmatic Research Program: A Response to Entman. Journal of Communication 52,2: 870 - 888. Available at: https://www.researchgate.net/

publication/229645364_News_Framing_as_a_Multiparadigmatic_Res earch_Program_A_Response_to_Entman (Accessed on 22 July 2021.) https://doi.org/10.1111/j.1460-2466.2002.tb02578.x

De Kadt, E. 2020. Promoting Social Justice in Teaching and Learning in Higher Education through Professional Development. Teaching in Higher Education: Critical Perspectives 25,7: 872 - 887. Available at: https://www.tandfonline.com/doi/pdf/10.1080/13562517.2019.161768 5 ?

casa token=s529SQvO9IgAAAAA:xNAdUknMWbwwqLL3khtCCM 5QAeLe1X7r5LUEoSvdCoZd m5hNhudZTTMs8WOUTVRxKtZpI3 RV-tz (Accessed on 22 July 2021.) https://doi.org/10.1080/13562517.2019.1617685

Elçi, A. \& B.C. Devran 2014. A Narrative Research Approach: The Experiences of Social Media Support in Higher Education. In Zaphiris, P. \& A. Ioannou (eds): Learning and Collaboration Technologies: Designing and Developing Novel Learning Experiences. LCT 2014. 
Lecture Notes in Computer Science 8523: 36 - 42. Cham: Springer. Available at: https://link.springer.com/content/pdf/10.1007\%2F978-3319-07482-5 4.pdf (Accessed on 22 July 2021.)

Erikson, E.H. 1963. Childhood and Society. $2^{\text {nd }}$ Edition. New York: WW Norton \& Company. (Original work published 1950.)

Greene, M. 1971. Curriculum as Consciousness. Available at:

https://maxinegreene.org/uploads/

library/curriculum_consciousness.pdf (Accessed on 20 February 2018.)

Greene, M. 2007. Imagination and Becoming. Bronx Charter School of the Arts. Available at:

https://maxinegreene.org/uploads/library/imagination_bbcs.pdf (Accessed on 5 March 2020.)

Hall, M. 2015. Institutional Culture of Mergers and Alliances in South Africa. In Curaj, A., L. Georghiou, J. Cassingena Harper \& E. EgronPolak (eds): Mergers and Alliances in Higher Education. Cham: Springer. Available at: https://link.springer.com/chapter/ 10.1007/978-3-319-13135-1 8 (Accessed on 23 July 2021.)

Hammarberg, K., M. Kirkman \& S. de Lacey 2016. Qualitative Research Methods: When to Use Them and How to Judge Them. Human Reproduction 31,3: 498 - 501. Available at:

https://academic.oup.com/humrep/article/31/3/498/2384737

(Accessed on 22 July 2021.) https://doi.org/10.1093/humrep/dev334 PMid:26759142

Heleta, S. 2016. Decolonisation: Academics must Change What they Teach, and How. Available at: https://theconversation.com/decolonisationacademics-must-change-what-they-teach-and-how-68080 (Accessed on 06 June 2018.)

Hofer, J., H. Busch, A. Chasiotis, J. Kar̈tner \& D. Campos 2008. Concern for Generativity and its Relation to Implicit Pro-Social Power Motivation, Generative Goals, and Satisfaction with Life: A Cross-Cultural Investigation. Journal of Personality 76,1: 1 - 30. Available at: https://www.unimuenster.de/imperia/md/content/psyifp/aekaertner/hofer_et_al__ 08 _ p-

_concern_for_generativity_and_its_relation_to_implicit_prosocial_po wer motivation.pdf

(Accessed on 23 July 2021.) 
Ronicka Mudaly et al.

https://doi.org/10.1111/j.1467-6494.2007.00478.x

PMid:18186709

Husu, L. 2001. On Metaphors of the Position of Women in Academia and

Science. Nordic Journal of Feminist and Gender Research 9,3: 172 -

181. Available at: https://www.researchgate.

net/publication/248996538_On_metaphors_on_the_position_of_wome

n_in_academia_and_science (Accessed on 22 July 2021.)

https://doi.org/10.1080/713801035

Hyland, K. 2018. Narrative, Identity in Academic Story Telling. ILCEA 38:

1 - 16. Available at: https://journals.openedition.org/ilcea/4677

(Accessed on 22 July 2021.)

Jansen, J. 2017. Decolonizing the University Curriculum Given a Dysfunctional School System? Journal of Education 68: 3 - 13. Available at: http://www.scielo.org.za/pdf/jed/n68/02.pdf

(Accessed on 22 July 2021.)

Iveković, R. 2019. Epistemological Fractures: The Decline of Western

Paradigms. Beyond the Current Epistemic Hegemony? Journal of

Postcolonial Writing 55,6: 755 - 768. Available at:

https://www.tandfonline.com/doi/pdf/10.1080/17449855.2019.168015

0? needAccess=true (Accessed on 23 July 2021.)

https://doi.org/10.1080/17449855.2019.1680150

Kim, J. 2016. Narrative Data Analysis and Interpretation: 'Flirting with

Data'. In Kim, J. (ed.): Understanding Narrative Inquiry: The Crafting and Analysis of Stories as Research. Available at:

https://methods.sagepub.com/ book/understanding-narrative-inquiry

(Accessed on 22 July 2021.)

Kincheloe, J.L. 2008. Critical Pedagogy and the Knowledge Wars of the

Twentieth Century. International Journal of Critical Pedagogy 1,1: 1 -

22. Available at: http://freire.education.

mcgill.ca/ojs/public/journals/Galleys/IJCP011.pdf (Accessed on 12

March 2013.)

Kogan, M. 2000. Higher Education Communities and Academic Identity.

Higher Education Quarterly 54,3: 207 - 216. Available at:

https://onlinelibrary.wiley.com/doi/abs/10.1111/1468-2273.00156

(Accessed on 22 July 2021.)

https://doi.org/10.1111/1468-2273.00156

Lange, L. 2017. 20 Years of Higher Education Curriculum Ppolicy in South 
Africa. Journal of Education 68: 31 - 57. Available at: https://journals.ukzn.ac.za/index.php/joe/article/view/379/819 (Accessed on 22 July 2021.)

Lawler, S. 2009. Identity: Sociological Perspectives. Cambridge: Polity Press.

Leibowitz, B. \& V. Bozalek 2014. Access to Higher Education in South Africa: A Socialist-realist Account. Widening Participation in Lifelong Learning 16,1: 91 - 109. Available at:

https://www.researchgate.net/publication/263046717_Access_to_high er_education_in_South_Africa_A_social_realist_account (Accessed on 22 July 2021.) https://doi.org/10.5456/WPLL.16.1.91

Mama, A. 2006. Pursuing Gender Equality in the African University. International Journal of African Renaissance Studies 1,1: 53 - 79.

Available at: https://www.researchgate.net/publication/ 232966969_Pursuing_Gender_Equality_in_the_African_University (Accessed on 22 July 2021.)

Matthews, S. 2015. Shifting White Identities in South Africa and the Struggle for Racial Justice. Phronimon 16,2: 112 - 129. Available at: http://www.scielo.org.za/pdf/phronimon/v16n2/07.pdf (Accessed on 22 July 2021.) https://doi.org/10.25159/2413-3086/3821

McAdams, D.P. \& E. de St. Aubin 1992. A Theory of Generativity and its Assessment through Self-report, Behavioural Acts, and Narrative Themes in Autobiography. Journal of Personality and Social Psychology 62: 1003 - 1015. Available at: https://www.researchgate.net/publication/ 232504200 A Theory of Generativity and Its Assessment Throug h_Self-Report_

Behavioral Acts and Narrative Themes in Autobiography (Accessed on 22 July 2021.) https://doi.org/10.1037/0022-3514.62.6.1003

McAlpine, L. 2016. Why Might you Use Narrative Methodology? A Story about Narrative. Eesti Haridusteaduste Ajakiri 4,1: 32 - 57. Available at: https://www.researchgate.net/publication/

301638297 Why might you use narrative methodology A story a bout_narrative (Accessed on 22 July 2021.) https://doi.org/10.12697/eha.2016.4.1.02b

McCune, V. 2019. Academic Identities in Contemporary Higher Education: 
Ronicka Mudaly et al.

Sustaining Identities that Value Teaching. Teaching in Higher Education 26,1: 26 - 35. Available at:

https://www.tandfonline.com/doi/epub/10.1080/13562517.2019.16328 26? needAccess=true (Accessed on 23 July 2021.)

https://doi.org/10.1080/13562517.2019.1632826

Mendieta, J.A. 2013. Narrative Research: An Alternative Approach. Folios 37: 135 - 147. Available at:

https://www.researchgate.net/publication/262502285_Narrative_resear ch_An_alternative_approach_to_study_language_teaching_and_learni ng (Accessed on 22 July 2021.)

https://doi.org/10.17227/01234870.37folios135.147

Mhlauli, E., E. Salani \& R. Mokotedi 2015. Understanding Apartheid in South Africa through the Racial Contract. International Journal of Asian Social Science 5,4: 203 - 219. Available at:

https://www.researchgate.net/publication/299132487_Understanding Apartheid in South Africa through the Racial Contract (Accessed on 22 July 2021.) https://doi.org/10.18488/journal.1/2015.5.4/1.4.203.209

Mitchell, C. 2008. Getting the Picture and Changing the Picture: Visual Methodologies and Educational Research in South Africa. South African Journal of Education 28: 365 -383. Available at:

https://www.ajol.info/index.php/saje/article/view/25163 (Accessed on the 22 July 2021.) https://doi.org/10.15700/saje.v28n3a180

Mitchell, C. \& N. de Lange 2011. Community-based Participatory Video and Social Action in Rural South Africa. In Margolis, E. \& L. Pauwels (eds): The Sage Handbook of Visual Research Methods. London: Sage.

Mudaly, R. 2012. Gazing Inward: Teaching in the Postgraduate Milieu. Alternation 19,2: 38 - 56. Available at:

http://alternation.ukzn.ac.za/Files/docs/19.2/03\%20Mud.pdf (Accessed on 22 July 2021.)

Mudaly, R. 2015. Creating my Academic Self and Space: Autoethnographic Reflections on Transcending Barriers in Higher Education. Journal of Education 62: 35 - 57. Available at:

http://joe.ukzn.ac.za/Libraries/No 62 2015/Creating my academic s elf_and_space_-

autoethnographic reflections on transcending barriers in higher e ducation.sflb.ashx (Accessed on 22 July 2021.) 
https://doi.org/10.17159/i62a03

Mudaly, R. 2018a. Towards Decolonising a Module in the Pre-service Science Teacher Education Curriculum: The Role of Indigenous Knowledge Systems in Creating Spaces for Transforming the Curriculum. Journal of Education 74: 47 - 66. Available at: http://www.scielo.org.za/pdf/jed/n74/05.pdf

(Accessed on 22 July 2021.) https://doi.org/10.17159/2520-9868/i74a04

Mudaly, V. 2018b. Decolonising the Mind: Mathematics Teachers Explore Possibilities for Indigenising the School Curriculum. Journal of Education 74: 67 - 84. Available at:

https://journals.ukzn.ac.za/index.php/joe/article/view/914/1283

(Accessed on 22 July 2021.) https://doi.org/10.17159/2520-9868/i74a05

Naicker, L. 2013. The Journey of South African Women Academics with Particular Focus on Women Academics in Theological Education. Studia Historiae Ecclesiastic 39, Supplement: 325 - 336. Available at: http://www.scielo.org.za/pdf/she/v39s1/18.pdf

(Accessed on 22 July 2021.)

Naicker, I., D. Pillay \& S. Blose 2020. Restorying Lived Lives in Educational Research: Storyboarding as a Creative Space for Scholarly Thinking in Narrative Analysis. Journal of Education 18: 126 - 141. Available at: https://journals.ukzn.ac.za/index.php/joe/article/view/1525/1733

(Accessed on 22 July 2021.)

Ndlovu-Gatsheni, S.J. 2018. Epistemic Freedom in Africa: Deprovincialization and Decolonization. London: Routledge.

https://doi.org/10.4324/9780429492204

Osei-Kofi, N., R.A. Shahjahan \& L.D. Patton 2010. Centering Social Justice in the Study of Higher Education: The Challenges and Possibilities for Institutional Change. Equity and Excellence in Education

43,3: 326 - 340. Available at:

https://www.tandfonline.com/doi/pdf/10.1080/

$\underline{10665684.2010 .483639 ? \text { needAccess }=\text { true }}$

(Accessed on 23 July 2021.)

https://doi.org/10.1080/10665684.2010.483639

Osei-Kofi, N. 2013. The Emancipatory Potential of Arts-Based Research for Social Justice. Equity \& Excellence in Education 46:1, 135 - 149. 
Ronicka Mudaly et al.

Available at: https://www.researchgate.net/

publication/263249102_The_Emancipatory_Potential_of_Arts-

Based Research for Social Justice (Accessed on 22 July 2021.)

https://doi.org/10.1080/10665684.2013.750202

Prinsloo, P. 2020. Claiming Humanity, Reclaiming Hope: The Role of Higher Education in the $21^{\text {st }}$ Century. Revista Nacional de Administacion 11,1:85-93. Available at: https://www.scielo.sa.cr/ pdf/rna/v11n1/1659-4932-rna-11-01-85.pdf (Accessed on 22 July 2021.) https://doi.org/10.22458/rna.v11i1.3001

Radlwimmer, R. 2017. Decolonisation and Gender: Perspectives on Literatures and Cultures of the Americas. Gender and Research 18,2:

16 - 34. Available at: https://www.researchgate.net/

publication/321988774_Decolonisation_and_Gender_Perspectives_on _Literatures_and_Cultures_of_the_Americas (Accessed on 23 July 2021.) https://doi.org/10.13060/25706578.2017.18.2.369

Ramohai, J. 2019. A Black Woman's Perspective in Understanding Transformation and Diversity in South African Higher Education.

Transformation in Higher Education 4. Available at:

https://www.researchgate.net/publication/332350762 A black woma n's_perspective_on_understanding_transformation_and_diversity_in_ South_African_higher_education (Accessed on 05 April 2021.)

Savin-Baden, M. \& L. van Niekerk 2007. Narrative Inquiry: Theory and

Practice. Journal of Geography in Higher Education 31,3: 459 - 472.

Available at: https://www.researchgate.

net/publication/232927132_Narrative_Inquiry_Theory_and_Practice

(Accessed on 23 July 2021.)

https://doi.org/10.1080/03098260601071324

Sayed, Y., S. Motala \& N. Hoffman 2017. Decolonizing Initial Teacher Education in South African Universities: More than an Event. Journal of Education 68: 59 - 91. Available at:

http://www.scielo.org.za/pdf/jed/n68/05.pdf

(Accessed on 23 July 2021.)

Sellitti, A.D. 2009. Re-membering the Normative Black Female Body: A Critical Investigation of Race, Gender and Disability in Octavia Butler's Kindred and Toni Morrison's Sula. Unpublished Master's thesis, Faculty of the Graduate School of Arts and Sciences, Georgetown University, USA. Available at: 
https://repository.library.georgetown.edu/

bitstream/handle/10822/553044/sellittiAliciaDawn.pdf?\%20sequence= 1 \&isAllowed=y (Accessed on 15 May 2021.

Sheble, L. \& B. Wildemuth 2009. Research Diaries. In Wildemuth, B. (ed.): Applications of Social Research Methods to Questions in Information and Library Science. Santa Barbara, CA: Libraries Unlimited.

Shiva, V. 1993. Monocultures of the Mind: Understanding the Threats to Biological and Cultural Diversity. Indian Journal of Public Administration. Available at:

https://journals.sagepub.com/doi/abs/10.1177/0019556119930304 (Accessed on 12 March 2018.)

Shober, D. 2014. Women in Higher Education in South Africa. Advances in Gender Research 19: 315 - 332. Available at:

https://www.researchgate.net/publication/289858086_Women_in_

Higher_Education_in_South_Africa (Accessed on 23 July 2021.)

https://doi.org/10.1108/S1529-212620140000019014

Statistics South Africa 2017. Education Series. Volume III. Pretoria: Statistics South Africa. Available at:

http://www.statssa.gov.za/publications/Report\%2092-01-

03/Education_Series_iii.pdf (Accessed on 22 July 2021.)

Stevens, S. \& N. Patel 2015. Viewing Generativity and Social Capital as Underlying Factors of Parent Involvement. School Community Journal 25,1: 157 - 174. Available at:

https://files.eric.ed.gov/fulltext/EJ1066211.pdf

(Accessed on 22 July 2021.)

UNESCO International Bureau of Education (IBE) 2014. The Role of Curriculum in Fostering National Cohesion: Opportunities and Challenges. Geneva, Switzerland: UNESCO IBE. Available at: http://www.ibe.unesco.org/sites/default/files/nationalcohesion_kenya_i bewpci 11 eng.pdf (Accessed on 22 July 2021.)

Van Heerden, M. 2017. 'The problem with decolonization': Jonathan Jansen Seminar. A summary of a keynote address delivered at the African University Dialogue hosted by Stellenbosch University, 24 November 2017. Available at: https://www.litnet.co.za/problem-decolonisationjonathan-jansen-seminar/ (Accessed on 22 July 2021.)

Van Laren, L., R. Mudaly, K. Pithouse-Morgan \& S. Singh 2013. Starting with Ourselves in Deepening our Understanding of Generativity in 
Ronicka Mudaly et al.

Participatory Educational Research. South African Journal of Education 33,4: 1 - 16. Available at:

http://www.scielo.org.za/pdf/saje/v33n4/02.pdf (Accessed on 22 July 2021.) https://doi.org/10.15700/201412171320

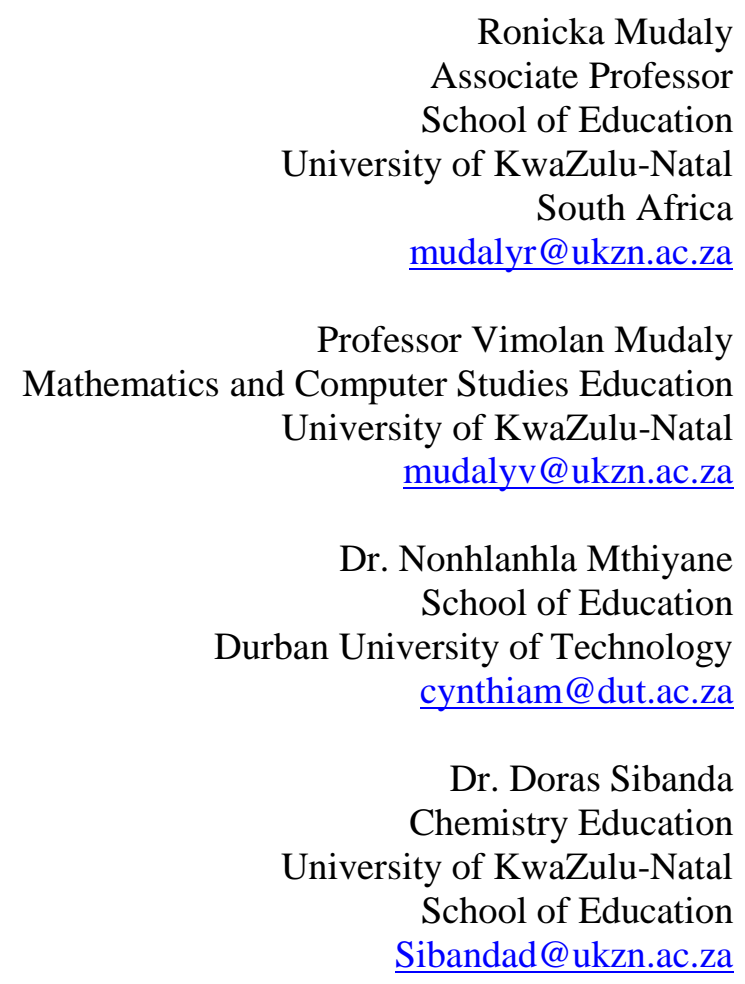

